\title{
A PLACE-BASED PROJEKTEK SAJÁTOSSÁGAI A KREATIVITÁS KONTEXTUSÁBAN A WALDORF-PEDAGÓGIÁN KERESZTÜL
}

\section{Szerzők:}

Mészáros Tímea

Eszterházy Károly Egyetem

Egervári Júlia

Eszterházy Károly Egyetem

Első szerző e-mail címe:

meszarost@,ujs.sk

\section{Lektorok:}

\author{
Vass Vilmos (Ph.D.) \\ Budapesti Metropolitan Egyetem \\ Kiss Virág (Ph.D.) \\ Eszterházy Károly Egyetem
}

...és további két anonim lektor

\begin{abstract}
Absztrakt
Jelen tanulmány a „place-based” projektek sajátosságait a kreativitás kontextusában vizsgálja a Waldorf-pedagógián keresztül. A „place-based” pedagógia fogalma szorosan összefonódik a fenntarthatóságra és a társadalmi felelősségvállalásra neveléssel, a szociális munka megtapasztalásán keresztüli tanulással, az integrált környezeti neveléssel és a projektalapú tanulással. A magyarországi reformpedagógiához köthető iskolák legnagyobb közösségét a Waldorf-pedagógia alapján működő intézmények alkotják. Közös jellemzőjük az oktatási intézmény és a tanuló összekapcsolása a környezetével és a közösséggel, a társadalmi közeggel, melyben az múködik. Bemutatja a „place-based” projektek (inter)diszciplináris hátterét, különös tekintettel a tartalmát meghatározó elméleti megfontolásokra. Ismerteti a Waldorf-pedagógia módszertani alapjait a környezeti nevelés, elsősorban az iskolán kívüli, „,place-based” projektek kontextusában, rámutatva a kreativitás fejlesztésének lehetőségeire a két pedagógia keresztmetszetében.
\end{abstract}

Kulcsszavak: kreativitás, környezeti nevelés, place-based projekt, Waldorf-pedagógia

Diszciplinák: pedagógia, pszichológia

\footnotetext{
Abstract

CHARACTERISTICS OF PLACE BASED PROJECTS IN THE CONTEXT OF CREATIVTTY THROUGH WALDORF PEDAGOGY

The idea of "place-based" pedagogy is closely intertwined with the concepts of education for sustainability and social responsibility, learning through the experience of social work, integrated environmental education and project-based learning. The common intention of all is to connect the educational institution and the learner with
} 
its environment and the community, the social environment in which it operates. The present study examines the specifics of "place-based" projects in the context of creativity through Waldorf pedagogy. At the same time, it presents the disciplinary and interdisciplinary background of "place-based" projects founded on international literature and covers the theoretical considerations that determine its content. It describes methodological approaches of Waldorf pedagogy in the context of environmental education, with particular reference to out-of-school, place-based projects, pointing out the possibilities for developing creativity at the crossroads of the two pedagogies.

Keywords: creativity, enviromental education, place-based project, Waldorfpedagogy

Disciplines: pedagogy, psychology

Mészáros Tímea és Egervári Júlia (2021). A place-based projektek sajátosságai a kreativitás kontextusában a Waldorf-pedagógián keresztül. OxIPO - interdisz̧ciplináris tudományos folyóirat, 2021/1, 21-45. doi: 10.35405/OXIPO.2021.1.21

Jelen tanulmány központi eleme a placebased projekt, melyet a Waldorf-pedagógiára vonatkoztatunk. Ennek megfelelően először a place-based oktatást mutatjuk be a pedagógiai kutatások szemszögéből, majd a Waldorf-módszer művészeti-környezeti nevelési vonatkozásainak feltárására vállalkozunk a kreativitásra fókuszálva. A Waldorf-pedagógiát mind nemzetközi, mind hazai színtéren főleg elméleti szempontból közelítették meg elsősorban Steiner lejegyzett pedagógiai előadásai alapján. Empirikus kutatásokkal a tudományos publikációk szintjén kevesen foglalkoznak. A hazai Waldorf-iskolák mai gyakorlatára irányuló empirikus kutatásokat Pajorné Kugelbauer Ida 2013-as és Mesterházy Mária 2019-es doktori disszertációi összegzik. Tanulmányunkban a viszonylag új place-based fogalom mentén vizsgáljuk meg a komoly tradíciókkal rendelkező pedagógiát.

Az Egyesült Államokban az 1990-es évek második felében jelent meg elsőként ezen a néven a környezeti és természeti nevelés egyfajta megközelítéseként, és azóta is számos oktatási intézmény programjának részét képezi. Az idevágó szakirodalomban a David A. Gruenewald és Gregory A. Smith által szerkesztett Placebased Education in the Global Age: Local Diversity (2008) c. tanulmánykötet, ill. David Sobel Place-based Education Connecting Classrooms and Communities (2004) c. műve tekinthetők alapvetőnek, melyek átfogó képet nyújtanak a különböző modellekről és megvalósult projektekről. Az Egyesült Államokon kívül a 
hely- és közösség fókuszú oktatás főleg Ausztráliában és Új-Zélandon népszerű, de találhatunk európai törekvéseket is.

Magyarországon kifejezetten placebased oktatásról és programokról nem beszélhetünk, bár módszerei és elvei visszaköszönnek reform- és alternatív pedagógiai irányzatokban, erdei iskolák és alkotótáborok programjában, vagy akár a hátrányos helyzetű települések és iskolák fejlesztési - főleg civil- vagy alapítványi szervezésű - közösségi programjaiban. Neil Boland és Jocelyn Romero Demirbag (Boland, 2016, Boland és Demirbag, 2017) tanulmányaiban a hely fogalmát, és a közösség meghatározó szerepét, ill. ezen tényezőknek a Waldorf-pedagógiában elfoglalt helyét és alkalmazását, valamint a globalizálódó steineri pedagógia adaptív lehetőségeit, Európán kívüli terjedésének sajátosságait veszi számba.

A témát az alábbi tanulmányban történeti kitekintéssel elméleti szempontból vizsgáljuk, a kreativitással összefüggésben.

\section{A place-based pedagógia}

\section{fogalmi behatárolása}

A place-based (továbbiakban PB) oktatás elnevezése első hallásra idegenül csenghet. Hallatán olyan fogalmakra aszszociálhatunk, mint a problem-based, inquirybased és project-based tanulás, melyek innovatív, mondhatni jelenleg kimondottan divatos pedagógiai megközelítések. A PB-pedagógia bár szorosan kapcsolódik mindezekhez, lényegiségét tekintve ko- rántsem tekinthető újszerűnek (Smith, 2016).

A formális oktatás megjelenése és rendszerének - mint társadalmi szintű intézménynek - kiépülése előtt a szocializációs és tanulási folyamatok a családban és a helyi közösségben zajlottak. A hétköznapokban a megfigyelés, utánzás, felfedezés és együtt munkálkodás, a természeti és épített környezet megismerése természetes módon adta meg a tanulás kontextusát. Bár ez a tanulási folyamat informálisnak nevezhető, az mégis lehet tudatosan felépített és szisztematikus. Természeti népek, törzsek vagy természetközelben élő faluközösségek esetében így szállt generációról generációra a tudás, a különböző szakmák és közösségi szerepek ismerete, művelése, és biztosította a közösség fennmaradását (Smith, uo.).

A PB-pedagógia fő képviselői azt mondják, hogy a formális iskolai oktatás egyre inkább izolálódik az azt körülvevô és alakító közösség életétől, miközben korunk globális gazdaságpolitikai elvárásainak és egységesített tanterveknek próbál megfelelni, és a globális piac fogyasztóit és munkaerejét „termeli ki”. Elszakadva a közösségtől és a környezettől, és ezáltal az autentikus tanulási lehetőségektől, az előírt standardok teljesítése közben a tanulók gyakran találkozhatnak dekontextualizált instrukciókkal és problémákkal, melyek a tantermi közegben és kontextusban elvesztik összefüggéseiket, így nem is érik el a kívánt hatást 
(Gruenewald in Gruenewald, Smith 2008).

John Dewey már az 1890-es évek végén felhívta a figyelmet arra, hogy az iskolai oktatás-nevelés nem válhat el az élettől, a társadalmi közegtől, amelyben működik. A jövő gazdaságának és társadalmának elvárásai nem jósolhatók meg előre, így rugalmas, adaptív, találékony fiatalokká kell nevelni a tanulókat, hogy tehetségüket kibontakoztatva megtalálják helyüket a világban. Tulajdonképpen már ekkor lefektette a problémaközpontú, cselekvésen alapuló, önálló, felfedező tanulás modelljét. Ez az ismeretszerzés készségének megtanitását célozza meg, és az élethosszig tartó tanulás korai elképzelése fedezhető fel benne. A magolás és leckefelmondás helyett az önálló és kreatív gondolkodást és a képességek kibontakoztatását támogatta. Az általa elképzelt, ideális iskola „kölcsönhatásban áll: a) a gyermek otthoni környezetével, b) a természeti környezettel, amelybe beletartozik az iskola közvetlen és távolabbi körmyezete, c) az. üzleti élettel és a termeléssel, d) a tudománnyal (kutatással) és az arra elókészító egyetemmel." Mindez azért fontos, hogy a tanulás ne egy elvont, tényeken és ismereteken alapuló információ halmaz legyen, hanem egy élő, tapasztalati, fejlődési folyamat, mely összeegyeztethető a gyermek világával, valóságával (Dewey, 1912, 58. o. ). Dewey gondolatai és tapasztalatai inspirálóan hatottak és hatnak a PB-pedagógusok számára, sokan hivatkoznak rá úgy, mint az első amerikai place-community-based oktatóra.

A viszonylag új keletű globális nevelés pedagógiája is összecseng a PB-pedagógia elveivel. Azt mondja, hogy a globális problémákra globálisan kell válaszokat keresnünk, ugyanakkor igazán hatékonyan elsősorban a saját közösségünkben, saját lakhelyünkön tudunk cselekedni, változásokat elindítani, ill. a gyermekek számára a globális kérdések megértését a lokális példák tudják segíteni. Az adott közösséget érintő releváns, aktuális kérdések és problémák, a helyi adottságok, környezeti tényezők motiváló, aktivizáló hatásúak lehetnek az oktatás-nevelés folyamatára és élővé, megfoghatóbbá teszik az éppen tárgyalt témát.

Mai formájában és elnevezésében a PBoktatás az Egyesült Államok korai környezeti nevelési programjaiból nőtte ki magát. Az ökológiai irányzat és természeti nevelés egyik fontos képviselője, Sobel (1996) szerint, pedagógiájuk egyik alappillére az empatikus kapcsolódás másokhoz, legyen emberi vagy nem emberi életforma. A tanuló helyi környezetének felfedezése, a hely fogalom kialakítása, a helyhez és közösséghez kapcsolódó érzelmi szál az, ami elvezet a mélyebb érdeklődéshez és elkötelezettséghez a környezet megóvásáért és jobbá tételéért (Gruenewald, 2003).

A PB-oktatás egy olyan tanítási-tanulási stratégia, amelyet az oktatók városi, külvárosi, rurális és természeti környezetben is tudnak alkalmazni (bármilyen 
közegre és közösségre szabható), és amelyben a tanuló aktív szereplője a tanúlási folyamatnak. Fogalma összefonódik az integrált környezeti neveléssel, a fenntarthatóságra, társadalmi felelősségvállalásra neveléssel. Pedagógiájára jellemző a konfliktus és projektpedagógia módszereinek használata, fókuszban a tanulók belső motivációja és a cselekvés alapú tanulás van. Célja az iskola és a tanuló összekapcsolása a környezetével és a közösséggel, a társadalmi közeggel melyben működik, egyfajta együttműködés támogatása, a tanulók „életre való felkészítésének" és a tanulási folyamatban való nagyobb elköteleződésének érdekében (Powers, 2004; Deringer, 2017).

\section{A place-based oktatás fókuszpontjai és a kreativitás}

$\mathrm{Az}$ 1. ábra a PB-tanulás rétegeit ábrázolja. A kérdés az, hogy vajon honnan érdemes kiindulni? Mikor alakulhat ki előbb párbeszéd a tanuló és a pedagógus között, ha felteszi a kérdést, hogy melyik ország termeli a legtöbb hulladékot a világon, vagy ha saját lakhelyével kapcsolatban kell érzéseit, tapasztalatait, véleményét megfogalmaznia? A PB-pedagógia a személyes élményre, tapasztalatra és érzelmi bevonódásra épít, figyelembe véve a tanulók már meglévő ismereteit, vagy akár téves elképzeléseit. A kulturális örökségek ismerete és megőrzése ugyanannyira fontos lehet, mint a természeti értékek megóvása, egyben az iskola kör- nyezete, a lakóhely, és saját magunk helye a világban.

A PB-pedagógia fókuszpontjai közé tartozik a tanulóközpontúságon és személyes bevonódáson túl a rendszerszemlélet és az interdiszciplináris megközelítések. A tanulók valós példákon keresztül, saját kutatómunkát végezve közelebb kerülnek az ökológiai, gazdasági, politikai, kulturális szempontok és összefüggések megértéséhez. Több tantárgy és tudományterület találkozik és kapcsolódik egymással egyegy témakör feldolgozása során. A feladatok felépítése, az instrukciók és a tanárok facilitátori jelenléte az önállóságot, az aktív részvételt és a kreatív problémamegoldást támogatják (Net1).

\section{1. ábra: A place-based tanulás sæintjei forrás:} www.gettingsmart.com)

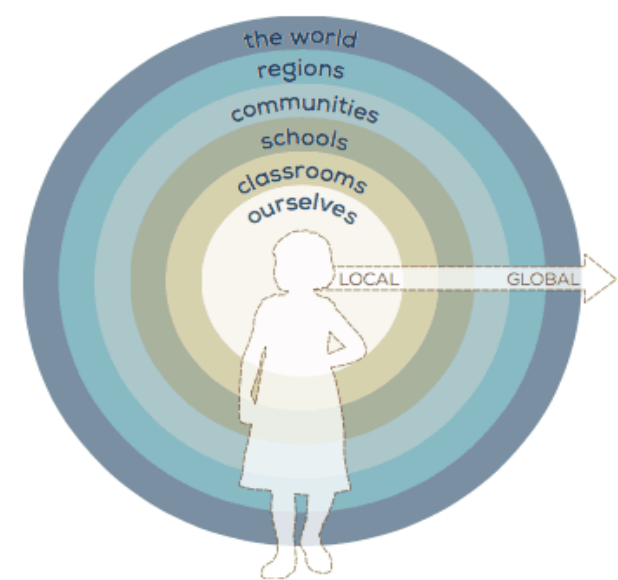

Gyakoriak a mûvészetalapú megközelítések is. Ezek az alkotó tevékenység által létrejövő érzelmi kapcsolódás lehetőségét hangsúlyozzák, ami megkönnyítheti az 
adott témával, hellyel, környezettel, élőlényekkel, személyekkel való kapcsolatteremtést, közelebb és akár más összefüggésbe hozhatja a tárgyalt témát, és kitágítja a módszerek, munkaformák, eszközök tárházát (Graham, 2007). Támogató környezetben a folyamatos kutatás, kísérletezés, a több lehetséges megoldás bátorítja a tanulókat, így kevésbé tartanak a hibázástól.

A művészetalapú megközelítés egy formája a design thinking, melynek elveit alkalmazva bármilyen téma feldolgozása lehet egy alkotó folyamat, ahol nem egy kifejezetten múvészi alkotás létrehozása a cél, hanem a kritikai gondolkodás, az eredeti ötletek megosztása, a folyamat megtervezése, a csoportos és önálló kreatív munka és problémamegoldás élményének megélése. A közösségi tevékenység, az együttműködés, az érzelmi és szociális kompetencia fejlesztése ugyanolyan fontos, mint az egyéni személyiségfejlődés és felelősségérzet kialakulása. Ezek elengedhetetlen feltételei az élethosszig tartó tanulás és a rugalmas, adaptív, innovatív hozzáállás meglétének. Ez a megközelítés minden PB-projektet és pedagógiai programot jellemez, iskolától, országtól, tantervtől függetlenül (Net1).

Ezek a fókuszpontok összhangban vannak az ún. 21. századi kompetenciák vagy készségek sorával. Az öt fó képesség: a kritikai gondolkodás, a kreativitás, az együttműködés, a metakogníció, és a motiváció (Lai és Viering, 2012). A gyors gazdasági, társadalmi és kulturális változások és az iskolában tanultak és a gyakorlati élet közötti szakadék áthidalásának igénye hívták elő a fejlesztendő területek újragondolását, és bár nem teljesen újak ezek a területek, a fókusz erősebb és nyomatékosabb, olyannyira, hogy nemzetközi szinten a tantervek és pedagógiai programok részévé váltak. Megjegyzendő, hogy a kompetencia még a mai napig vitatott fogalom. Mindenképp egy komplex rendszer, aminek fontos része a készségek és képességek egymásra épülése, de folyamatosan formálódik, egyre komplexebb és struktúraalkotó elemeiben gazdagodik (Vass, 2020). Érdekes kiegészítés lehet, hogy a World Economic Forum „Future of Jobs” kutatásában hogyan változott a Top 10 képességek sora. A kreativitás például 2015-ben a tizedik helyen szerepelt, majd 2020-ra már a harmadik legfontosabb képesség lett. A kreativitás alapfeltétele a divergens gondolkodás, és ez visszahat a listán első két helyen szereplő komplex problémamegoldó képességre és a kritikai gondolkodásra (Svéda, 2017). Ahogy korábban említésre került, a PB-pedagógiával oktatók is hangsúlyozzák a formális oktatás aktuális gazdasági, társadalmi, kulturális igényektől és problémáktól való elszakadását, ill. ennek negatív hatásait. Módszereik, tanítási-tanúlási modelljeik és a tanulási környezet, amit teremtenek, mind azt célozzák, hogy a helyi igényekre reagálva megvalósuljon ezen képességek sokoldalú fejlesztése, kibontakoztatása. 
Ezek az elvek és módszerek nem újkeletűek, különböző reform- és alternatív pedagógiák történetében találhatunk előzményeket. Bár a Waldorf-pedagógia az antropozófián alapul és más fogalomrendszerrel működik, mégis felfedezhetünk közös pontokat. Az egyik fontos alapvetés, hogy bár alapelveik egységesek és egzaktak, a Waldorf-pedagógia, legyen bárhol a világon, a helyi közösségre szabható, hiszen maga a közösség hozza létre.

\section{A waldorf-pedagógia fókuszpontjai}

A Waldorf-iskola pedagógiai programja mögött a szalutogenezis, a fenntartható emberi fejlődés elve húzódik meg. Ez azt jelenti a gyakorlatban, hogy a tanítási folyamat során olyan körülmények megteremtésére törekednek, amely a gyermek adottságainak függvényében lehetővé teszi a képességek legszélesebb skálájának legoptimálisabb kibontakoztatását, a társadalomba való beilleszkedés érdekében (lásd: A magyar Waldorf-iskolák kerettanterve, 2020).

„Ne azt kérdezzük: mit kell tudnia és mire kell képessé lennie az embernek a fennálló társadalmi rend számára, hanem: mire van hajlama és mit lehet fejleszteni az emberben?" (Steiner, 1993, 65. ). A Waldorf-pedagógia a nevelés mûvészetérôl beszél, nem a nevelés tudományáról. Már ez is jól jelzi, hogy a gyerekről való tudásnál (amihez hozzátartozik a gyerekekkel való kapcsolat életkorhoz, alkathoz, temperamentumhoz szabott módszertana) fon- tosabbnak tartják azt a művészi folyamatot, amelyben a tanár lehetőséget teremt a gyermek képességeinek kibontakoztatására. Az alapítóban, Rudolf Steinerben filozófiai, irodalmi, pszichológiai és orvosi előadásokat hallgatva ébredt fel az érdeklődés Goethe természettudományos kutatási módszerei iránt. Sokrétú érdeklődésének gyümölcseként 1894-ben látott napvilágot úttörő jelentőségű filozófiai műve, A szabadság filozófiája (Carlgren, 2013, 7.) Már itt megtalálhatók azok az alapgondolatok, amelye-ket később szellemtudományi tanában, az antropozófiában bontakoztatott ki (Czike, 1996). Steiner nevelésművészetének egyik alapvető célja a szociális képességek felébresztése és ösztönzése a gyermekben (Carlgren, 2013). 1913-ban megalapítja az Antropozófiai Társaságot, 1919-ben létrejön az első Waldorf-iskola Stuttgartban.

A Waldorf-pedagógia fókuszában a gyermekek testi, szellemi, lelki, akarati és szociális fejlődésének harmonikus egysége, azaz a teljes emberi személyiség kibontakoztatása áll. Szociálisan érzékeny, tudatos közösségformálással kívánnak hozzájárulni a társadalom fejlődéséhez. Az iskola életének minden területe ezt a célt szolgálja, azaz: nem csak a tanításnak, de felépítésében, működésében, az iskola egész életének kell példaként szolgálnia a gyermekek fejlődésében.

\section{Müvészettel nevelés}

A művészettel nevelés fogalmát az angol művészettörténész, Herbert Read 
vezette be a szakirodalomba. Education Through Art c. könyvében (1943) a művészet oktatásban betöltött szerepéről ír, illetve a művészet szerepéről a világ megismerésében, megértésében (Kárpáti, 2018.) Könyve legelején megfogalmazza alaptézisét, melyről azt állítja, nem túl újszerű, hiszen Platón már korábban világosan kifejezte: a múvészet kellene, hogy legyen az oktatás alapja. Úgy véli, Platón tézisét félreértelmezték, mivel nem tisztázott, hogyan használta a művészet fogalmát és mit tekintett az oktatás céljának. Read az oktatás, nevelés általános céljának az individuális értékek kibontakoztatását feltételezi, összhangba hozva azzal az organikus társadalmi közösséggel, melyhez az egyén tartozik. Levezeti az esztétikai nevelés fontosságát, az érzékelés és az önkifejezés képességének fejlesztésében betöltött szerepét, a különböző művészeti ágak komplex fejlesztő, nevelő hatását, párhuzamba állítva az érzékszervek, a test és a gondolatok együttműködésével. A művészet eszköztárának bevonása a világ, például a természet jelenségeinek megfigyelését, megértését segíti (Read, 1943).

A művészettel nevelés ma elterjedt fogalom, mely a művészetet funkcióba helyezi, a nevelés eszközeként fogja fel fogalompárja, a „művészetre nevelés”-sel szemben, ahol az önmagáértvaló (Trencsényi, 2000, Illés, 2009, Kiss, 2010, 2014, Bodóczky, 2012). A mûvészettel nevelés szempontjából a művészet eszköz (Mező és Mező, 2019b), ami más (nem mü- vészeti jellegû) nevelési-oktatási célok elérését segíti - vö.: Mező, 2018) és akár élménypedagógiai kontextusba is ágyazható az iskolai gyakorlatban (Mező K., 2015) A művészet nem csak a művelődés tárgya lehet, hanem a kreativitás csatornája, az érzelmi intelligencia fejlesztésének és akár az agresszió oldásának eszköze (Vekerdy, 2011).

A fogalom változásokon ment át, az egyes szerzők hasonló, de más-más tartalmakat kapcsolnak hozzá, azaz a fogalom fejlődött, változott, és mára kortárs tartalmakkal telt meg (Kiss, 2014). Steiner használta talán legelőször ezt a fogalmat, az ő értelmezésében a művészet-tudomány-vallás egységesen és harmonikus együttállásban kell, hogy megjelenjen. Pedagógiája törekvéseit az életkori jellemzőkből vezeti le, annak minden sajátossága ebbe a rendszerbe illeszkedik (Steiner, 1995).

Steinernél két hasonló jelenségről is beszélhetünk, egyrészt a nevelés-tanítás, mint művészet, másrészt a művészet, mint a nevelés-tanítás eszköze (Kiss, 2014). Steiner a pedagógiai folyamatot tanításmúvészetnek nevezi, melyben a tanár a tanítás művésze, a gyermek pedig „művészi” tevékenységek során fejlődik. A képességfejlesztés központi eleme a belső képek megteremtése, a fantázia mûködtetése, ami a gyerekben eleve meglévő növekedési és formáló erők segítségével jön létre. Az értelem kiala-kulásában és az alkotó gondolkodásban is szerepe van a fantáziának (Steiner, 2011). 
A 2. ábrán látható a képességfejlesztés három nagy területe: a gondolkodás, érzelem és az akarat. Ehhez a hármasságához köthető minden képességfejlesztésre iránuló tevékenység. A fejlesztési területek az emberi organizmus különböző részeihez kapcsolódnak. Míg a gondolkodás az idegrendszerhez, az érzelmek a ritmikus rendszerhez (légzési és vérke-ringési rendszer), addig az akarat mozgás- és anyagcsere folyamatokhoz köthető. A három rendszer fejlődésének csúcspontja más-más életszakra esik. Témánk szem-pontjából a 7. és 14. életév között szakasz a releváns, ekkor leginkább a ritmikus rendszer a domináns.

Steiner (2013) szerint a ritmikus rendszerre a művészi kifejezésformák és mûvészi tevékenységekkel lehet hatást gyakorolni. A művészi kifejező tevékenységek (ének és zene, képzőművészet, kézművesség, euritmia) az érzést és akaratot fejlesztik.

2. ábra: A Waldorf-pedagógia 8-14 éveskorosztályra vonatkozó képességfejlesztésének fogalomtérképe (forrás: Pajorné, 2013, 44. o.)

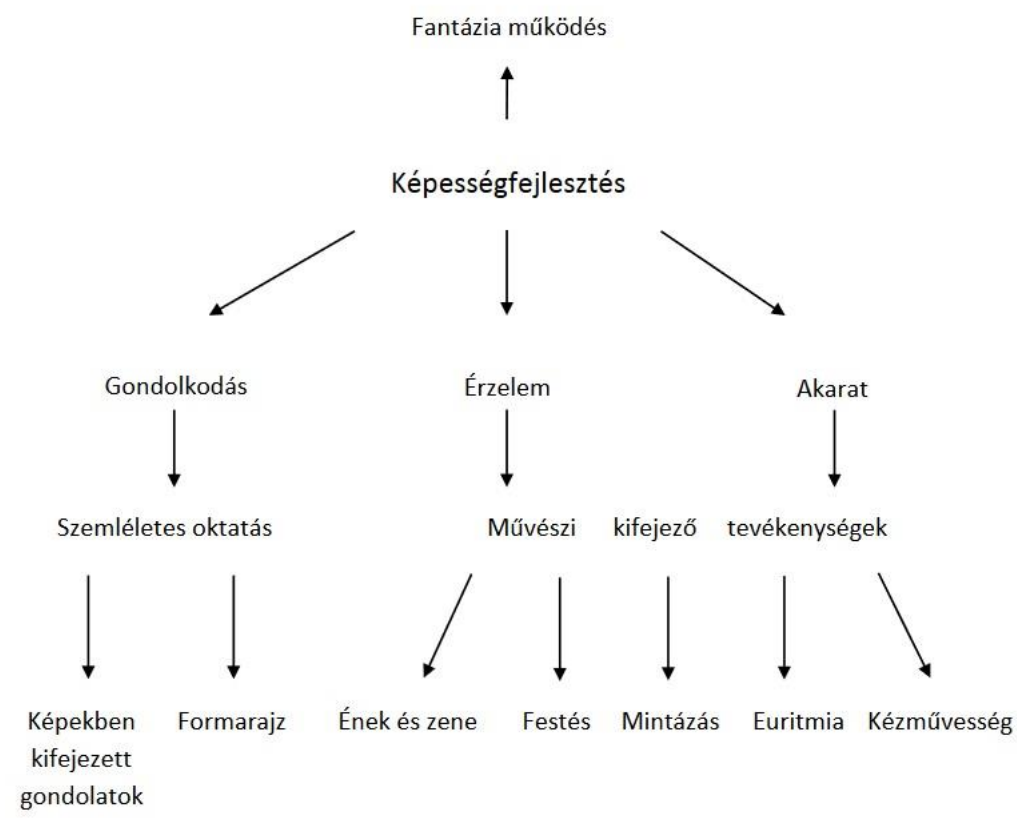


A különféle művészi tevékenységek egymásra hatást gyakorolnak, egymást segítik, és erősítik, olyan képességeket fejlesztenek, amelyek közvetlenül hozzájárulnak ahhoz, hogy a gyermek képessé váljon a gondolkodása és a cselekvése során több szempont, nézőpont figyelem bevételére és összehangolására. A művészi tevékenységek köztudottan motiváló erővel bírnak. A gondolkodás fejlesztésében a szemléletes oktatás módszerét alkalmazzák, a képzetek ill. fogalmak kialakításához. A szemléletes oktatás mesélés, történetmondás során fokozatosan bővíthető képek segítségével formálja a gyermek gondolkodását és nem merev, elvont definíciók által. A láttatás és képszerűség a formarajz feladatokban is megmutatkozik. A feljebb leírt steineri képességfejlesztés módszerei egy egymásra ható, összefüggő rendszert alkotnak (Pajorné, 2013, 43-44. ).

A művészeti nevelés körébe tartozó tantárgyak a közismereti tárgyakkal egységes tantervet alkotva a kötelező órák részei (A magyar Waldorf-iskolák kerettanterve az általános iskola 1-8. évfolyama számára, 2020). A művészetek jelenléte minden tantárgyban végigkíséri a tanulási folyamatokat. A népi kultúrát és játékot, a zenét és a táncot nem az élet egy szeleteként, hanem szerves részeként kezelik. Úgy vélik, ha a gyermek rendszeresen, „szívvel-lélekkel” éli meg a megismerés minden fázisát - a megfigyeléstől az elemzésen, fogalomalkotáson át azok elmélyüléséig -, akkor nem csak kész elemek „összerakására”, de kimúvelt képességei, biztos ismeretei révén „teremtésre" is alkalmas lesz. A Waldorf-iskolákban az önmegvalósítás nem cél, hanem eszköz, legyen szó a művészet bármelyik ágáról. A Waldorf-pedagógia művészi és gyakorlatias kézműves tevékenységeket egyaránt biztosít tanulói számára (Czike, 1996, 177-178.). Az alkotó tevékenységek elsősorban a rajz-formarajz-festés-grafikakézimunka-fafaragás tantárgyakon, ill. az epochákon belül valósulnak meg. A tanítás egészét áthatja a természetszerető és természet iránt felelősséget érző szemlélet.

\section{Kulcskompetenciák}

A Nemzeti alaptanterv (Net2) az Európai Unió által ajánlott kulcskompetenciákból kiindulva, a hazai sajátosságokat figyelembe véve az alábbiak szerint határozza meg az általános kompetenciákat, továbbá azokat, melyek egyetlen tanulási területhez sem köthetők kizárólagosan, hanem változó mértékben és összetételben épülnek a megszerzett tudásra, fejlődnek a tanulási-tanítási folyamatban.: 1. A tanulás kompetenciái, 2. Kommunikációs kompetenciák (anyanyelvi és idegen nyelvi), 3. Digitális kompetenciák, 4. Matematikai gondolkodási kompetencia, 5. Személyes és társas kapcsolati kompetenciák., 6. Kreativitás, önkifejezés, kulturális tudatosság, 7. Munkavállalói, vállalkozói kompetencia.

Az 1. táblázatban a kulcskompetenciákat a magyar Waldorf-iskolák kerettanterve (2020) alapján tekintjük át. 
1. táblázat: A NAT 2020 és a Waldorf-kerettanterv tantárgyi rendszereinek megfeleltetése a kulcskompetenciák.kal (forrás: A magyar Waldorf-iskolák kerettanterve (2020) alapján a Szerzö)

\begin{tabular}{|c|c|c|}
\hline \multicolumn{3}{|c|}{ A NAT 2020 és a Waldorf-kerettanterv tantárgyi rendszereinek megfeleltetése } \\
\hline Kulcskompetenciák & $\begin{array}{l}\text { A Nat } 2020 \\
\text { tantárgyai }\end{array}$ & $\begin{array}{c}\text { A Waldorf-kerettanterv } \\
2020 \text { megfelelő } \\
\text { tantárgyai }\end{array}$ \\
\hline \multirow{2}{*}{$\begin{array}{l}\text { A tanulás kompetenciái, Kommunikációs } \\
\text { kompetenciák (anyanyelvi és idegennyelvi), } \\
\text { Matematikai, gondolkodási kompetenciák, } \\
\text { Személyes és társas kapcsolati kompetenciák }\end{array}$} & $\begin{array}{l}\text { Magyar nyelv és } \\
\text { irodalom }\end{array}$ & \\
\hline & $\begin{array}{l}\text { magyar nyelv és } \\
\text { irodalom }\end{array}$ & magyar nyelv és irodalom \\
\hline \multirow{2}{*}{$\begin{array}{l}\text { A tanulás kompetenciái, Kommunikációs } \\
\text { kompetenciák (anyanyelvi és idegennyelvi), } \\
\text { Matematikai, gondolkodási kompetenciák }\end{array}$} & Matematika & \\
\hline & matematika & matematika \\
\hline \multirow{4}{*}{$\begin{array}{l}\text { A tanulás kompetenciái, Kommunikációs } \\
\text { kompetenciák (anyanyelvi és idegennyelvi), } \\
\text { Matematikai, gondolkodási kompetenciák, } \\
\text { Személyes és társas kapcsolati kompetenciák }\end{array}$} & $\begin{array}{l}\text { Történelem és } \\
\text { állampolgári } \\
\text { ismeretek }\end{array}$ & \\
\hline & történelem & történelem \\
\hline & $\begin{array}{l}\text { állampolgári } \\
\text { ismeretek }\end{array}$ & $\begin{array}{l}\text { társadalmi és állampogári } \\
\text { ismeretek (két választható } \\
\text { változat) }\end{array}$ \\
\hline & hon- és népismeret & \\
\hline $\begin{array}{l}\text { A tanulás kompetenciái, Kommunikációs } \\
\text { kompetenciák (anyanyelvi és idegennyelvi), } \\
\text { Kreativitás, a kreatív alkotás, önkifejezés és } \\
\text { kulturális tudatosság kompetenciái, Személyes } \\
\text { és társas kapcsolati kompetenciák }\end{array}$ & $\begin{array}{l}\text { Etika / hit-és } \\
\text { erkölcstan }\end{array}$ & szabad vallás \\
\hline \multirow{2}{*}{$\begin{array}{l}\text { A tanulás kompetenciái, Kommunikációs } \\
\text { kompetenciák (anyanyelvi és idegennyelvi), } \\
\text { Kreativitás, a kreatív alkotás, önkifejezés és } \\
\text { kulturális tudatosság kompetenciái, Matemati- } \\
\text { kai, gondolkodási kompetenciák, Személyes és } \\
\text { társas kapcsolati kompetenciák }\end{array}$} & $\begin{array}{l}\text { Természettudo- } \\
\text { mány és földrajz }\end{array}$ & \\
\hline & $\begin{array}{l}\text { környezetismeret 3- } \\
\text { 4. o. }\end{array}$ & $\begin{array}{l}\text { a kerettantervben ilyen tárgy } \\
\text { nem szerepel; a tárgy } \\
\text { témakörei beillesztve a hon- } \\
\text { ismeret és földrajz (1-12.o.) } \\
\text { és a természetisme-ret és } \\
\text { biológiatantárgyakba; ez } \\
\text { utóbbi 1-2. osztályban más } \\
\text { tantárgyakban jelenik meg, } \\
\text { 3-12. osztályban pedig } \\
\text { önálló órakerete van. }\end{array}$ \\
\hline
\end{tabular}




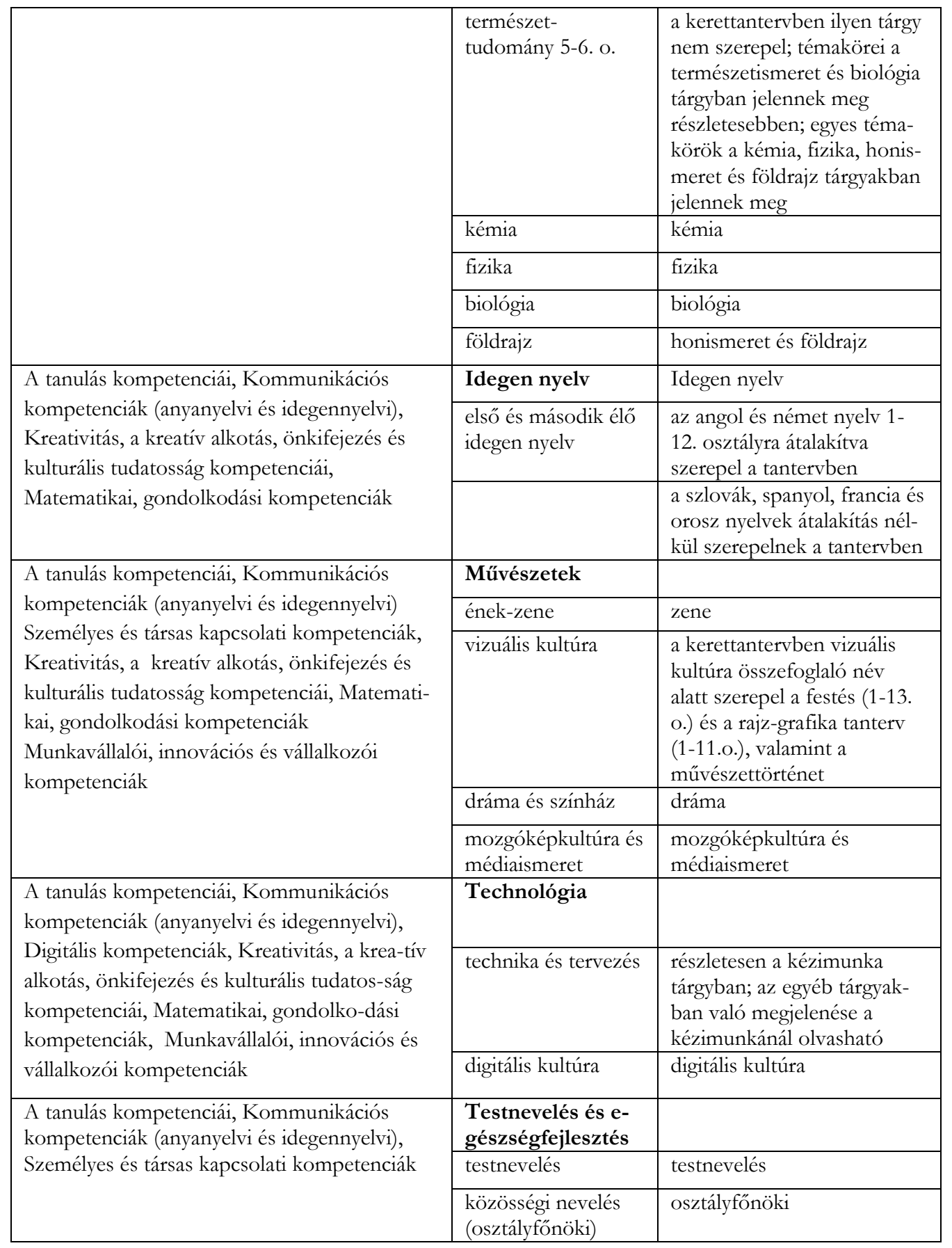


A tanulás kompetenciái: Kisiskolás korban a tanulás elsősorban a tananyag átélésén és a tevékenységeken keresztül valósul meg. A gondolkodási tevékenységet a tanulási-tanítási folyamatokban is az érzésekkel és az akarattal hozzák kapcsolatba. A későbbiekben a belső átéléssé vált érzékszervi tapasztalatokat hatja át a gondolkodás ereje, így jutnak el tanulók valós ok-okozati összefüggésekhez.

Kommunikációs kompetenciák (anyanyelvi és idegennyelvi): A tanulási tevékenységekben való személyes jelenlét és az interperszonális érintkezések biztosítják az alapot ahhoz, hogy a tanulók képesek legyenek érzéseiket és gondolataikat személyes interakciókban a kontextusnak megfelelő módon közvetíteni. A művészetoktatás célja a szociális és érzelmi nevelés, az empatikus részvétel fejlesztése a kommunikációban is. A tanulók első osztálytól két élő idegennyelvet tanulnak.

Digitális kompetenciák: A digitális kultúra tárgy anyaga elméleti alapozást és gyakorlati nevelési tanácsokat ad a szülők és a tanárok kezébe.

Matematikai, gondolkodási kompetenciák alatt olyan felkészültséget értünk, amely alkalmassá teszi a tanulókat arra, hogy különböző helyzetekben tudatosan, praktikusan cselekedjenek. A gondolkodási kompetencia többfajta képességen keresztül realizálódik (pl. rendszerezés, kombinativitás, deduktív és induktív következtetés, érvelés) és ezeknek más területen is működő komponenseknek kell lennie. $\mathrm{Az}$ osztálytanítói rendszerben a peda- gógus a tevékenységeket és a tantárgyakat interdiszciplináris módon kezeli, így a gondolkodási kompetenciákat tantárgyakon átívelő módon is fejleszteni tudja. A praktikus gondolkodás fejlesztése a Waldorf-iskola egyik legfontosabb törekvése.

A személyes és társas kapcsolati kompetenciák: A tanulók szociális képességeinek, együttműködési készségének, egymás felé fordulásának fejlesztése, gyakorlása a Waldorf-iskola egyik legfontosabb feladata. Az együttműködésen alapuló tanúlás, a közös művészeti előadások, fellépések az önismeret, a társas együttélés megalapozói. Az inkluzív közösségépítés az el- és befogadó, együttmúködő és ösztönző légkör kialakítását jelenti az iskolában.

A kreativitás, a kreativ alkotás, önkifejezés és kulturális tudatosság kompetenciái: A mûvészeti nevelés éves zárómunkái 8. és 12. osztályban a tudatos ember nevelését célozzák meg. Az első vizsga nyolc év tanulmányaira való visszatekintés, a második- a tizenkét éves Waldorf-képzés lezárásaként a tanuló jövendő életútjának irányai felé mozdul. A tanuló képességeiben kiteljesedve döntéseket meghozni tudó emberként hagyja el az iskolát. Az aktív tanuláson keresztül fejlődik a kreatív gondolkodásuk.

Munkavállalói, innovációs és vállalkorói kompetenciák: a Waldorf-pedagógia három alappillére az élet-, a szociális- és a gazdasági ismeretek. A pénz szerepének tudatos végiggondolásán alapuló gazda-ságtan tanterv célja ötödiktől nyolcadik osztályig 
alapvető gyakorlati-logikai kész-ségeket kialakítani. Az egyéni és csoportos kezdeményezőkészség az innovációs kompetencia megszerzésének alapja. A projektszemlélet, a tantárgytömbösítés, az éves munkák, a művészeti projektek, a mindennapi élethez való kapcsolódás igénye a vállalkozói attitűd kialakítását segítik.

A fentiek alapján a Waldorf-kerettanterv pedagógiai-nevelési szemlélete jól illeszkedik a kompetencia-fejlesztésre építő tanuláshoz, összhangban áll az aktuális Nemzeti alaptanterv és az Európai Unió ajánlásaival.

\section{Projektalapú tanulás}

Témánk fontos eleme az interdiszciplinaritás, ezért a Waldorf-pedagógia lehetőségeit a projektalapú tanulás szempontjából is áttekintjük. A 20. század valamennyi pedagógiai elképzelésének meghatározó eleme az aktív tanulás, melynek középpontjában a tanuló aktív tevékenysége áll, ahol előtérbe kerül saját elképzelése, önálló gondolatainak megfogalmazása és közreadása. A tanulók változatos tevékenységek útján alakítják ki saját tudásukat, miközben kritikusan értékelik az elsajátítandó ismereteket, mely segítheti a későbbi reflektálást, és egyúttal felkeltheti bennük a visszajelzés igényét. Amennyiben a feladatok felkeltik kíváncsiságukat, előtérbe kerül a problémamegoldó gondolkodás és a kreatív, örömteli tevékenység. Az aktív tanulás eredményességét a pedagógus facilitátori sze- repben segítheti. Az aktív tanuláshoz kapcsolódó tanulási-tanítási módszerek: autentikus-, felfedezéses- (discovery), kutatásalapú- (inquiry-based), jelenségalapú- (phenomenon-based), problémaalapú- (problem-based) és a projektalapú (project-based) tanulás (Katona és tsai., 2020).

A projektalapú tanulás során a tanulók különböző forrásokból információkat gyűjtve, egy közösen választott komplex témáról hoznak létre egy produktumot vagy előadást (Great Schools Partnership, s.a.). A cél a társadalmi környezet és az iskolán kívüli programok tanulásba történő bevonása a készségek nagyobb körének mozgosításával. A projekt produktumának létrehozása akár több héten vagy hónapon át is folyhat, és nem feltétlenül kötődik tantárgyakhoz, tanórához (Katona és tsai., 2020).

Petrőczi (2020) szerint a 2020-as Nemzeti alaptantervben $A_{z}$ egységességröl és a differenciálásról, valamint a módszertani alapelvekröl szóló fejezetben korszerű pedagógiai módszerekkel találkozhatunk, megjelenik: az aktív tanulás, a tanulói kompetenciafejlesztés, az egyénre szabott tanulási lebetöségek biztosítási kötelezettsége, a tanulói együttmüködésen alapuló tanulás, valamint a több multidiszciplináris óra megszer-vezésére irányuló ajánlás. Ezen foglalkozások során a tanulók a tudnivalók integrálásán keresztül egyszerre több tudományterülettel ismerkednek meg. A tanárok kooperálása során a több tantárgy ismereteit integráló témákat feldolgozó foglalkozások közös 
tanítás keretében valósulnak meg, ezáltal erősödik a tanári együttmúködés.

A Waldorf-pedagógia alapeleme az epocha, olyan témakörökre szervezett ciklikus tanulásszervezési eljárás, melyben az egyes logikailag összetartozó témakörök (pl. kémia-fizika-biológia tantárgyban) tömbösítve kerülnek tárgyalásra: egy ideig nagy óraszámban van napirenden a téma, majd utána a következő időszakban a tantárgy szünetel, és más tárgy témakörére kerül sor egy másik epochában (Segédanyag Waldorf-intézményben tanfelügyeleti ellenőrzést vagy pedagógusminősítést folytató szakértők számára, 2019). Az epochális (korszakos) oktatás egyfajta tantárgytömbösítés, ahol a magas óraszámú időszakokban (epochákban) lehetőség nyílik a tanulóközpontú módszerek, például a projekt alkalmazására. A főoktatás tárgyai (pl. történelem, embertan, állattan, kémia, matematika, geometria stb.) nem 45 perces órakeretekben jelennek meg, hanem 3-4 héten keresztül tömbösítve, összefüggő egészként, jellemzően a nap első két órájában megszakítás nélkül. A „témában élést” az órarend többi órája is támogatja. Ha a tanulók a reneszánsz művészetről tanulnak a főoktatás ideje alatt, akkor a rajzórákon az éppen aktuális technikával reneszánsz szobrokat, épületeket rajzolnak, a dramaórákon reneszánsz szövegeket dolgoznak fel, az osztályterem falain a folyamatban lévő epocha produktumai láthatók, tehát az osztály aktívan benne él a témában. Ez a korszakos óraszervezés elősegíti a tananyagban való elmélyülést, a figyelem és az érdeklődés tartós fókuszáltságát, illetve lehetővé teszi, hogy különböző megközelítésben, változatos eszközökkel és munkaformákkal sajátítsanak el egy-egy témakört. Az interdiszciplinaritás eredendően jellemző a Waldorf-pedagógiára, lásd epochális rendszer. Ezt a Nemzeti alaptanterv a kulcskompetenciák és a műveltségi területek strutúrájával és egymásra építettségével erősíti. A fentiek alapján elmondható, hogy a Waldorfpedagógiának kiválóak a lehetőségei az aktív tanulás, esetünkben a projektalapú tanulás szempontjából.

A tantárgytömbösítés lehetősége bármelyik iskola számára elérhető. Nyilvánvalóan összetett feladatról van szó, melynek megvalósítása azonban nem lehetetlen. Amennyiben a környezeti nevelés lehetőségeiről gondolkodunk, a projektalapú tanítás-tanulás módszere kézenfekvő megoldásként kínálkozik, hiszen ez a terület nem a természetismeret vagy környezetismeret tárgyakban jelenik meg, hanem kereszttantervi tartalomként, amely bármelyik műveltségi területen integrálható.

\section{Fenntarthatóságra nevelés a waldorf-iskolákban}

A környezeti tudatosság elsősorban a környezethez füződő érzelmi viszonyulás bázisán nyugszik; ez a fajta „érzelmi ráhatás" a Waldorf-pedagógia sajátossága. A természeti és épített környezet isme- 
retét, a szerető, féltő és védő gondolkodásmódot nem lehet a gyerekbe sulykolni - természetes anyagokra építkező környezetben, élményszerzéssel, a gyermek érzelmeire és érzékeire erősen ható, kreativitását fejlesztő mûvészeti neveléssel, felfedező-kutató tevékenykedtetéssel, drámapedagógiával - melyek a Waldorfpedagógia eszközei, sajátjai - nagyobb esélyünk van egy természetszerető és ezáltal védő szemlélet kialakulására. A gazdag érzelemvilágú ember mindig fogékonyabb az őt érő hatásokra, a környezetével sokrétűbb a kapcsolata. A természetszeretet, a környezetvédelem ezáltal evidenciaszerűen adódik, mert közvetlen a kapcsolat az emberi lét és a természet között. A környezettudatos magatartás alapigényként jelentkezik az iskolafenntartói és az iskolaműködtetői oldalon. A Waldorf-iskolák tantervének felépüléséből pontosan kiviláglik, hogy már az alsóbb osztályokban törekednek folyamatos kapcsolat kialakítására a valós világgal és a világ természetes folyamataival. A tanulók olyan önfenntartó természetességgel működő történelmi-gazdasági mesterségekkel, tevékenységekkel találkoznak, és olyan, sok esetben régi-népi eljárással, gyakorlatokkal ismer-kednek meg, aminek önmagában példa-mutató értéke van. A felső tagozaton pedig a természettudományi tanterveknek tematikailag is részét képezik ezek a kérdések, ami biztosítja az ismeretek koncentrikus bővülését, elmélyülését (A magyar Wal- dorf-iskolák kerettanterve az általános iskola 1-8. évfolyama számára, 2020).

\section{Természetes anyagokra építkező környezet- és tárgykultúra}

A Waldorf-pedagógia nagy hangsúlyt fektet a saját tapasztalatokból származó sokrétú élmény feldolgozására. A sokféle minőség, különbözőség megtapasztalása, átélése céljából a természetes anyagok használatát preferálják a műanyag eszközökkel szemben. A kisgyermeket környező felnőtt világ felelőssége és egyben feladata, hogy biztosítsa az ingergazdag fizikális és pszichés környezetet, és hogy ne „csapják be” érzékleteiben a fajsúly és a felületi viszonyokat „tévesen” reprezentáló tárgyak (Segédanyag Waldorfintézményben tanfelügyeleti ellenőrzést vagy pedagógusminősítést folytató szakértők számára, 2019).

Az osztálytermi és iskolai évszakasztalok a természet ritmusának, évszakonkénti változásának, megújulásának, a természettel való összhangnak mindennapos megélésére hivatottak. A tananyagok feldolgozásánál, a művészeti foglalkozásokon, kézműves tevékenységeknél valamennyi évfolyamon megjelennek a gyerekek által gyűjtött természetes anyagok és eszközök (termések, virágok, ágak, gyökerek, levelek), és -alapanyagok, mint a gyapjú, méhviasz, agyag. Az osztálytermeket, az iskola épületét jellemzően a gyerekek, a szülők és a pedagógusok közös, természetes anyagokból készített 
alkotásai, batikolt textíliák, különböző faragványok, agyagedénykék, vesszőből lámpaernyők, kosarak díszítik. A gyerekek székein a szülők által készített nemezpárnák foglalnak helyet. A természetes anyagokra építkező környezet- és tárgykultúra is azt segíti, hogy minél közelebb kerüljenek a természethez, annak szerves részeként vigyázzanak mindenre, ami körülveszi őket. A Waldorf-iskolák sajátosságai közé tartozik, hogy a gyerekek maguknak kötik meg a fafurulyájuk tokját, a gyermek első hangszerét (lírát) pedig a szülők faragják meg fából. Természetes anyagokból készült hangszereket használnak, méhviasz krétát, növényi alapanyagú akvarell festéket.

\section{A vizuális- és környezeti nevelés összefonódása}

A környezeti nevelés és az alkotó tevékenységek összekapcsolódása mind a vizuális nevelés anyag- és eszközhasználatában, mind a feldolgozásra, bemutatásra kerülő témákban megnyilvánul. Feladatként jelenik meg a természetben rejlő törvényszerűségek, szabályszerűségek megfigyelése és megragadása vizuális kifejezőeszközökkel. Míg az alsó tagozat hangsúlyos anyaga a színek világával való ismerkedés és az állat- és növényvilág felfedezése, addig a felsőbb évfolyamokon a történelem, földrajz tárgyak ismeretanyagait kísérik a rajz-festés órák. Az első 3 évben az élő környezetről, a megszemélyesített természeti, környezeti jelenségekről szóló mesék dominálnak a tanításban, azonban a 9. évben kezdődő Steiner által Rubikonnak nevezett korosztály már igényli a valóságos elemeket a történetekben, ezt a paraszti kultúrával való ismerkedéssel segítik. A 4. osztályban a valóságos elemet a túrák, faluházak, parasztudvarok, templomok, malmok, múzeumok látogatása biztosítja. Jellemző vizuális feladat a térképrajzolás a szúkebb környezetükről fejből, felülnézetből (Carlgren, 2013).

A korábban már említett formarajz olyan Waldorf-specifikum, ahol a tanító mond egy mesét, amelyben az adott szereplő kalandokat él át, különféle (geometrikus, természeti) formákkal találkozik, azokat alaposan megfigyeli. Mindezt szavakkal képszerūen részletesen leírja, elmondja, azután lerajzolja, s őt követve lerajzolják a gyerekek is. Mindezek az elemek egyetlen képben egyesülnek, egyenesekből és görbékből álló színes rajzban. Ezek a mesék, játékok és mozgások vezetnek el az 5. osztályig, ahol a formarajz belenő a szabadkézi geometriába (Carlgren, 2013).

\section{Place-based jellegü projektek a waldorf-iskolákban}

A Waldorf-iskolák az általános iskolai évek első felében kiemelt fontosságúnak tartják a rendszeres kapcsolatot az erdővel, a természeti környezettel. Ahol ezt az iskola helyi adottságai megengedik, ott az iskolai élet szerves egészébe emelik be az erdőjárást, ahol erre nincs lehetőség, ott a 
környező tájat. Nem az időjárás határozza meg, hogy alkalom nyílik-e az erdő felkeresésére, hanem a gyerekek alkalmazkodnak megfelelő ruházatukkal a váltakozó időjáráshoz: a tűző napsütéstől a szakadó esőig. Ennek köszönhetően lehetőség nyílik megismerni az erdő összes arcát. Az érzékszervi tapasztalatok teszik lehetővé a gyermekek számára a világ megismerését. Minél több természetes tárggyal és élőlénnyel találkozik élő közegében a kisgyermek, annál jobb alap képződik a későbbi tantárgyak megértésére. Waldorf-specifikum a fára mászás tudományának elsajátítása.

Míg az alsó évfolyamokon a környezettudatosság alapjait sajátítják el tanulók (az iskola környékén élő állat- és növényvilággal ismerkednek meg), addig a harmadik osztályban a földművelés epocha keretében olyan tanulmányi kiránduláson vesznek részt, amelyen a földműveléssel, a növénytermesztéssel és állattenyésztéssel találkozhatnak aktív résztvevőként. A paraszti életmóddal való ismerkedés során a különféle haszonnövények-, állatok fejlődését a magtól egészen a feldolgozásig követik. A programokban mindig a megélt munkálkodás során megtapasztalt erőfeszítés, az átlátható folyamatok megélése dominál. Ezen kívül is adódik lehetőségük erdei iskola keretében természetközeli tájakkal, ill. a tágabb környezettel való megismerkedésre.

A harmadik osztály egyik nagy kihívást jelentő feladata a földművelés epocha és a házépítés. Ez egy közös munkálkodást jelent valamely nagyobb volumenű alkotáson, lehet ez kuckó építése, kemence készítése vagy éppen egy fakerítés kialakítása. Általában az iskola udvarán építenek közösen 3-4 nap leforgása alatt egy objektumot. Egy házépítő projektben először a főoktatáson van szó pl. a házépítés kialakulásáról, a parasztház felépítéséről (képek kíséretében), melyet le is rajzolnak a gyerekek. A későbbiek során a szakórákon részt vesznek a szülők is, és elkezdődik a közös munka. A munkálatokat a szülők jelenlétükkel, munkájukkal, építőanyaggal támogatják. A befejezést többnyire egybekötik egy udvarszépítéssel, melyre az egész iskola közösségéből várják szülőket és gyerekeket. A szülői összefogásnak köszönhetően így a gyerekeknek valódi munkaélményben van részük. A Waldorf-pedagógia nagy hangsúlyt fektet a család aktív és alkotó részvételére az iskola életében, elősegítve és erősítve a családi és iskolai nevelés egységét.

Boland és Demirbag (2017) szerint az akadémikusok már felismerték a PB- és a Waldorf-pedagógia kapcsolatát, sőt az első igazi PB-pedagógiának tekintik. Ô maga is leszögezi, hogy elméletileg a Waldorf-iskolák és óvodák a PB-elveit közvetítik és gyakorolják már több mint száz éve. Ugyanakkor felteszi a kérdést, vajon tényleg ez működik-e a Waldorfoktatásban nemzetközi szinten? Megvan-e minden Waldorf-intézménynek a sajátos jellege, a helyi kultúrához, társadalomhoz, 
környezethez való kapcsolódása? Előfordulhat-e, hogy az angliai iskolákban vagy akár Hawaii-n inkább „németesnek” érezhető a tanterv, mint „helyinek”? $\mathrm{Ha}$ igen, jó-e ez így, kell-e ezzel a jelenséggel foglalkozni, ezen gondolkodni? Milyen mértékben és milyen módon valósítható meg a steineri pedagógia a világ különbözó pontjain?

Boland azt hangsúlyozza, hogy minden iskola egy kulturális, geog-ráfiai, politikai környezetbe ágyazódik, minden régiónak és országnak megvan a maga történelme és nézőpontja, melyből a világtörténelmet magyarázza és szemléli. Ez tükröződik a tantervben, és meg is kell jelenjen természetes módon, így válik autentikussá, élővé. Úgy véli, a tanterv egy élő dolog kell legyen, ami aktualizálható, figyelembe veszi ezeket a tényezőket és az aszerint tanító pedagógusok is azonosulni tudnak vele. Korábbi kutatásai alapján az idő, a hely és a közösség kontextusában hoz fel példákat és intéz elgondolkodtató kérdéseket a nagyrészt Waldorf-pedagógusokból álló hallgatóságához (Boland, 2016).

\section{Kreativitással tanítás}

A PB és Waldorf-pedagógia cselekvésés élményalapú pedagógiája szintén nem új keletû. Az élménypedagógia fogalma a 20. századtól használatos és a reformpedagógiáktól elválaszthatatlan, de gyökerei régebbre nyúlnak vissza. A 17 . században már Comenius is említ élményalapú módszereket, mint például az ,iskola, mint színjáték", ahol a játékon keresztül történik a tanulás, vagy például John Locke is hangsúlyozza a megismerés, tapasztalás fontosságát, a természet iránti érzékenységet, illetve az önálló problémamegoldás, kutatás támogatását. Rousseau pedig felhívja a figyelmet a tanulási környezet meghatározó szerepére. John Dewey: Experience and Education c. könyve (1938) tulajdonképpen az első publikált élménypedagógiai tanulmány, mely kiindulási alapot ad. Feltételezi, hogy az oktatás akkor válhat hatékonnyá, ha minőségi és valódi élményt nyújt a diákok számára. Maslow (1964) megközelítése alapján ide kapcsolható az ún. csúcsélmény generálása, amely az önmegvalósítás érzetét, boldogságot és kielégültséget hozza magával. Többféle kontextusban lehet jelen, mint például egy kreatív tevékenység vagy a természet élvezete. A csúcsélmény öröme összekapcsolódhat a kreatív problémamegoldás, alkotófolyamat felszabadító, energizáló hatásával (Mező K., 2015).

A Waldorf-pedagógia is élménygazdagságra törekszik, nagyon tudatos és szisztematikus módon. Klein (2020) szerint a konstruktív kreativitás belső feltételei közé tartozik 1. a nyitottság az élményekre, 2. az értékelés belső színtere és 3. a szabad játék a gondolatokkal, formákkal. Ahol ez a három feltétel teljesül, ott konstruktív alkotás születik. Aki nyitott az élményekre, annak belső és külső késztetései (formák, hangok, színek, érzetek, emlékek) akadálytalanul végigfutnak az 
idegrendszerén, úgy élve meg a jelenségeket, ahogy azok az átélés pillanatában keletkeznek.

A Waldorf-pedagógia a fogalmak, elképzelések, észlelések, érzékletek közötti falak átjárhatóságát biztosítja azzal, hogy az egyes tárgyak tanítását úgy tervezi és formálja, hogy a tanulási-tanítási folyamatok tudatosan hassanak egy másik műveltségi területen megszerezhető készségekre, képességekre is. Nemcsak a hasonló műveltségi- és tudományterületeket kapcsolja össze, hanem a humánés reál tárgyak közötti átjárhatóságot is figyelembe veszi.

A kreativitás alapvető feltétele, hogy az alkotás értékét ne a külvilág dicsérete vagy kritikája határozza meg (Klein, 2020). A Waldorf-iskola nem osztályzatokkal értékel. Célja segítséget nyújtani ahhoz, hogy a gyermek a fejlődési útján haladva képes legyen kiválasztani a neki megfelelő tanulási formákat, így váljon a világ felé nyitott, testileg egészséges, lelkileg szabad és szellemileg kreatív emberré, aki tisztában van saját értékeivel. Az érdemjegyekkel történő osztályzás helyett az értékelés folyamatában a Waldorf-tanulók alkotó résztvevőként vannak jelen. Ennek során egy választott (elméleti, művészeti és gyakorlati összetevőket tartalmazó) témát dolgoznak fel egyénileg projekt jelleggel az év során, melyet a tanév végén bemutatva hitelesebben adnak számot arról, mire képesek valójában.

A kreatív tanulás feltétele a tanítástanulás folyamatában, hogy a tanulók a megfelelő inputot a megfelelő tanulási környezetben megkapva, azt kognitív és emocionális módon is feldolgozzák, melynek sikerességét az organizáció, azaz a teljesítmény eléréséhez vezető folyamatok szervezése biztosítja. Ez a lényege röviden az OxIPO-modellnek (Mező és Mező, 2019b), mely hatékonyan alkalmazható tanulásfejlesztési és egyéb módszertanok kidolgozása esetében, tanulmányunk szempontjából kiemelten a direkt és indirekt tanulás és képességfejlesztés területén, illetve segítheti művészettel nevelési módszertan kidolgozását, továbbá interdiszciplináris kutatásokat (Mező és Mező, 2019b).

A kreatív iskola legfőbb jellemzője a kreatív folyamatot segítő tanulási környezet, ahol az iskola mindent elkövet annak érdekében, hogy megismerje a tanulót. A tanuló érdeklődési köre, érdéke, tanulási stílusa, családi környezete olyan hozzáadott értéke a kreatív iskolának, amelyre érdemes időt szánni (Vass, 2012).

A Waldorf-iskolák legfontosabb nevelési elveinek egyike a gyermek személyiségének minél mélyebb és sokoldalúbb megismerése, a benne rejlő értékek felfedezése, ezek gondozása, megadva minden lehetőséget a kibontakoztatásukhoz. A kreatív iskola másik fontos jellemzője a hatékony együttmúködés, amely egyszerre jelenik meg a tanári csoportokban, a projektekben, a közösségi programokban és a bizalommal teli légkörben (Vass, 2012). 
A Waldorf-iskolákban a művészeti tanítás fogalma különböző formákban valósulhat meg: 1. a tanárok maguk is a különféle művészeti ágak, formák gyakorlói, ismerői, 2. művészi módszereket alkalmaznak az óráikon (festés, rajzolás, szavalás, zene stb.), 3. a tanulás-tanítás folyamatára struktúrájában is művészi eredetiség, képalkotás és kreativitás jellemző, 4. a tanulók hangulatának befolyásolására megfelelő esztétikai környezet teremtésére törekednek.

\section{Konklúzió}

Jelen tanulmányban arra vállalkoztunk, hogy megvizsgáljuk a place-based- és a Waldorf-pedagógia közös pontjait, amihez az ismeretelméleti hátterükre történő rátekintés nyújtott segítséget. A fentiek alapján számos dologban különbözik. Míg a Waldorf-pedagógia a steineri szellemtudomány, az antropozófia emberképén alapszik, mely az embert test, lélek és szellem hármas egységeként értelmezi a művészet-tudomány-vallás harmonikus együttállásában, addig a PB-pedagógia nem szellemi és/vagy spirituális princípiumokra épít, sokkal inkább a demokratikus nevelés által a demokratikus értékek és a társadalom éltetése a célja. Módszerei nem teljesen egzaktak. Azok egyfajta célés keretrendszert adnak különböző tanúlási modellek összekapcsolására, melyek az adott iskolára, helyre, közösségre szabhatók. Nincs egy személyben szellemi atyja és megteremtője, inkább több kiemelkedő PB-oktató munkássága, jól működő intézmények adnak iránymutatást, és közvetítik az évek során kikristályosodott alapelveket, és egyben folyamatos megújulás figyelhető meg. Azt vallják, hogy ha a PB-oktatás erőteljes, személyre vagy csoportra szabott, új és jól múködő tanulási modellekkel párosul, az egy magasan funkcionáló demokráciát, fenntartható módon fejlődő társadalmat eredményezhet, melynek polgárai jól informáltak és elkötelezettek. Bár ez megegyezik a Waldorf-pedagógia céljaival, mégis egészen más paradigma mentén múködik.

A Waldorf-iskolákat világszerte a szülők hozzák létre gyermekeik számára, miután előzőleg két-három éven át a steineri pedagógiát értők közremúködésével elméletben és gyarkorlatban tanulmányozták. Ezek az intézmények világszerte egységes elvek alapján múködnek, de a környezethez adaptálódva, egymástól mégis jelentősen különböznek. Míg a Waldorfiskolák szervezetének és működésének alapelvei az egyes intézményekben a Waldorf-paradigmán belül, a steineri előadásokkal összhangban valósulnak meg, addig a PB-pedagógia esetében nem beszélhetünk hasonló emberképről. Azonban mindkét pedagógia közös vonása, hogy a helyi sajátosságoknak megfelelően, gyakorlat-centrikusan szerveződnek, ill. a társadalmi aktivitáson és a természet, az élőlények tiszteletén alapulnak. A PBpedagógia és a Waldorf-pedagógia további közös pontjai, hogy valóságos feladatokat nyújtanak, növelik a tanulók 
önállóságát, autonómiáját. Olyan célokat, motivációkat biztosítnak, mellyel a közösség azonosulni tud. Az együttmúködés fejleszti a toleranciát, az empátiát. A differenciált szerepvállalás, munkamegosztás sikeresélyeket nyújt a közösség minden tagja számára. A tevékenységen, tapasztalaton alapuló tanulás képességfejlesztő hatású, növeli a természetes, spontán tanulás arányát. Erősíti a tanulók felelősségtudatát, javítja döntésképességüket, s ezen keresztül önismeretüket. Bevonja a tevékenységbe a tanulók iskolán kívüli idejét is. Láthatóvá teszi számukra a közvetlen egyéni és közösségi hasznosulás fogalmát. Mindkét pedagógia arra nevel és tanít, hogy a társadalom más tagjaival együtt olyan közösséget legyenek képesek alkotni, ami megfelel a kor kérdéseinek, kihívásainak. A tanulókat önálló felelősségtudatra neveli, akik szabadságukkal felelősen képesek bánni, akik szociálisan érzékenyek. A tanulókban alapvetően meglévő, a környezetük és a világ iránti nyitottságra alapoz. A fentiek alapján kijelenthetô, hogy a minden területet átszövő művészeti és környezeti nevelés hatásaként a tanulók alkotóképessége, kreativitáskésztetése, problémamegoldó érzékenysége és a természetiránti érzékenysége, ill. az alkotótevékenységekhez és a természethez füződő pozitív szokásaik és attitűdjük sokoldalú támogatást kap a Waldorf-pedagógiában és a PB-oktatásban egyaránt. Mindkét pedagógia középpontjában a felelős életvitelt folytató, környezetét nem vissza- utasító, hanem emberségesebbé tevő emberkép áll.

Az általános nevelési célok között ma kiemelt helyen áll a kreativitásra nevelés és ezzel összefüggésben a problémamegoldó képesség, a kritikai gondolkodás fejlesztése. Nagy szükség lenne arra, hogy kívülről, objektíven és tudományos igénnyel kerüljön feldolgozásra az alternatív pedagógiák hatása a kreativitásra, a kritikai gondolkodásra különös tekintettel a magyarországi Waldorf-iskolákban. A pedagógusképzés oldaláról fontos lenne megfogalmaznunk, hogy ma milyen elvárásaink vannak az iskolával szemben és mi ebben a múvészettel nevelés, ill. a közösség szerepe? Mit és hogyan tudunk a PB-pedagógiából és a Waldorf-módszerekből hasznosítani a közoktatásban?

A hazai közoktatásban folyó művészetiés környezeti nevelés színvonalát jelentős mértékben javíthatná a már gyakorló pedagógusok további módszertani képzése, egy új, merőben eltérô szemlélet elültetése, megerősítése, a technikai feltételek javítása. A pedagógusképzés nem csak a környezeti nevelés tanításában szorul reformokra - a téma hihetetlenül gazdag és aggasztóan aktuális. A PB- és a Waldorf-pedagógia keresztmetszetében elhelyezkedő, a közösségben és a közösségért végzett alkotó tevékenységek során elsajátított attitűdök, kedvtelések döntő jelentőséggel bírhatnak a felnövekvő generáció életében, így ezek kutatása kiemelkedő fontosságot könyvelhet el. 


\section{Irodalom}

A magyar Waldorf-iskolák kerettanterve az általános iskola 1-8. évfolyama számára (2020). Letöltés: 2020. 12.10. Web: https://waldorf.hu/wpcontent/uploads/WALDORFKERETTANTERV-2020-1-8.pdf

Bodóczky, I. (2012). Kis könyv a vizuális müvészeti nevelésröl. VKFA, Budapest.

Boland, N. (2016). A Sense of Place within the Waldorf Curriculum: Three Audits of Place, Time and Community. Letöltés: 2020.12 .10 Web: https://www.academia.edu/32943479 $\angle$ BOLAND Sense of Place_pdf

Boland, N. és Demirbag, J. R. (2017). (Re)inhabiting Waldorf education: Honolulu teachers explore the notion of place. Educational Journal of Living Theories. Vol. 10(2): 20-50

Bujdosóné, P. A. és Gesztelyi, H. (szerk.) (2020). A teljesség harmóniája 1. A müvészettel nevelés értelmezései. Hajdúböszörmény: Didakt Kft.

Carlgren, F. (2013). Szabadságra nevelés. Török Sándor Waldorf-Pedagógiai Alapítvány, Solymár.

Czike, B. (szerk.) (1996). Bevezetés a pedagógiába. Eötvös József Könyvkiadó, Budapest.

Comenius, J. A. (1653). A látható világOrbis sensualium pictus (Rövidítése: Orbis pictus). Budapest.

Dewey, J. (1912). Az iskola és a társadalom. Lampel, Budapest.

Dewey, J. (1938). Experience \& Education. New York, NY: Kappa Delta Pi.
Deringer, S. A. (2017). Mindful PlaceBased Education: Mapping the Literature. Journal of Experiential Education 2017, Vol. 40(4) 333 -34.

DOI.10.1177/1053825917716694

Graham, M. A. (2007). Art, Ecology and Art Education: Locating Art Education in a Critical Place-Based Pedagogy, Studies in Art Education, Summer, 2007, Vol. 48, No. 4. 375391. DOI: $\underline{10.2307 / 25475843}$

Great Schools Partnership (s.a.). Projectbased learning In The Glossary of Education Reform. Letöltés: 2020.01.04. Web: https://www.edglossary.org/projectbased-learning/

Gruenewald D. A. és Smith A. G. (szerk.), (2008). Place-Based Education in the Global Age: Local Diversity, New York: Psychology Press

Gruenewald D. A. (2003). The Best of Both Worlds: A Critical Pedagogy of Place, Educational Researcher, Vol. 32, No. 4.. 3-12.

Illés, A. (2009). Múvészetterápia a közoktatásban: elméleti lehetôségek és etikai megfontolások. Új Pedagógiai Szemle, 56. 233-240.

Katona N., Konrád Á., Perlusz A., Polányi V., Porogi A. és Sisa Pné (2020). A tanulás és tanítás súlypontjai-szempontok a korszerū tanításhoz és tanuláshoz. Letöltés: 2020. 01.04. Web:

https://www.oktatas2030.hu/wpcontent/uploads/2020/10/a-tanulass-tanitas-sulypontjai.pdf 
Kárpáti A. (2018). Mûvészetpedagógia, Education Through Arts, Magyar Tudomány 179(2018)6, 761-772

Kiss, V. (2010). Mûvészeti nevelés, művészettel nevelés, múvészetterápia. Iskolakultúra, 10. szeparátum, 18-31. Letöltés: 2020.12.10. Web: http://epa.oszk.hu/00000/00011/001 51/pdf/2010-10_szeparatum.pdf

Kiss, V. (2014). A müvészet mint nevelés, a nevelés mint müvész̨et. Letöltés: 2020. 12.10 .

Web: http://nevelestudomany.elte.hu/down loads/2014/nevelestudomany 2014_1 69-81.pdf

Klein, S. (2020). Intelligencia, kreativitás, kompetencia. Edge 2000 Kiadó, Budapest.

Lai, E. R. és Viering, M. (2012). Assessing 21st Century Skills: Integrating Research Findings. Letöltés: 2020.12.10. Web: http://images.pearsonassessments.co $\mathrm{m} /$ images/tmrs/Assessing 21st Cent ury Skills NCME.pdf

Locke, J. (1693). Gondolatok a nevelésről. In Kornis Gyula (Szerk.) (1914). Pedagógia Könyvtár IV. Katolikus Középsikolai Tanáregyesület, Budapest.

Maslow, A. H. (1964). A theory of human motivation. In H. J. Leavitt, \& L. R. Pondy (Eds.). Readings in managerial psychology. Chicago: University of Chicago Press. pp. 6-24

Mesterházy, M. (2019). Érzelmi elemek Waldorf-tanárok identitásának alakulásában. Letöltés: 2020.12.29.Web: https://ppk.elte.hu/dstore/document L379/Mesterh $\%$ C3\%A1zy $\% 20 \%$ C3\% 89rzelmi $\% 20$ elemek $\% 20$ Waldortan $\% \mathrm{C} 3 \% \mathrm{~A} 1 \mathrm{rok}^{2} \% 20$ szakmai $\% 20$ ident it $\%$ C3 $\%$ A 1 s $\%$ C3 $\%$ A 1 nak $\% 20$ alakul $\%$ C3\%A1s\%C3\%A1ban.pdf

Mező, K. (2015). Kreativitás és élménypedagógia. Kocka Kör, Debrecen. ISBN 978-615-5267-07-9

Mező, F., és Mező, K. (2019a). Mûvészeti diagnosztikai eszközök a művészettel nevelés szolgálatában. Különleges Bánásmód, 5. (3). 91-102. DOI 10.18458/KB.2019.3.91

Mező, F. és Mező, K. (2019b). Az OxIPO-modell - az interdiszciplináris kutatások egy lehetséges értelmezési kerete. OxIPO - interdiszciplináris tudományos folyóirat, 2019/1, 9-21. doi: 10.35405/OXIPO.2019.1.9

Pajorné, K. I. (2013). Viquális nevelés a Waldorf-iskolában. A rajzi képességek fejlódése és fejlesztése egy longitudinális vizsgálat tükrében. Letöltés: 2020.09.05. Web: http://ppkteszt.elte.hu/file/Pajorne Kugelbauer_Ida_Dissz.pdf

Petrőczi, G. (2020). A módositott Nemzeti alaptanterv bevezetésével kapcsolatos szakmai teendök. Letöltés: 2020.01.04. Web: https://www.petroczigabor.hu/cikkek Ligazgato kollegaknak/modositott na t bevezetese.html

Powers, A. L. (2004): An Evaluation of Four Place-Based Education Programs. The Journal of Environmental Education, Summer 2004.,Vol.35., 
No.4.. DOI. 10.3200/JOEE.35.4.17$\underline{32}$

Read, H. (1943): Education through Art. London: Faber

Segédanyag Waldorf-intézményben tanfelügyeleti ellenörzést vagy pedagógusminösitést folytató szakértők számára. (2019). Magyar Waldorf Szövetség. Letöltés: 2020.12.29. Web:

https://www.oktatas.hu/pub bin/dlo ad/sajatoldal/Segedanyag szakertokne k Waldorf 2019.06.pdf

Smith, G. (2016). The Past, Present and Future of Place-Based Learning. Letöltés: 2020.01.29. Web: The Past, Present and Future of Place-Based Learning (gettingsmart.com)

Steiner, R. (2018). A nevelés müvészete. Metodika-didaktika. Genius Kiadó, Budapest.

Steiner, R. (1993). A gyermek nevelése szellemtudományi szempontból. Jáspis Kiadó, Budapest.

Steiner, R. (1995). Nevelömüvészet. A tanitás metodikéja és a nevelés életfeltételei. Jáspis Kiadó, Budapest.

Steiner, R. (2011). A müvészet küldetése a világban. Génius Kiadó, Budapest.

Svéda, D. (2017). A kreativitás mint versenyelóny. Letöltés: 2020.12.29. Web: https://brandbook.hu/2017/04/akreativitas-mint-versenyelony

Trencsényi, L. (2000). Müvészetpedagógia, elmélet, tanterv, módszer. Okker Kiadó, Budapest.

Vass V. (2012). A kretív iskola. Anyanyelvpedagógia 2012. 1.sz. Letöltés: 2020.12. 31. Web: http://www.anyanyelvpedagogia.hu/cikkek.php?id=374

Vass, V. (2020). A tudásgazdaság és a 21. századi kompetenciák összefüggései, Új Munkaügyi Szemle I. évf. 2020 / 1. sz.

Vekerdy T. (2011.) Éržlmi biztonság, Kulcslyuk kiadó, Budapest

Wildgruber, T. (2016). Painting and Drawing in Waldorf Schools. Classes 1 to 8. Edinburgh: Floris Books,

Online források

Net1: Getting Smart and Teton Science Schools - What is Place-based Education and Why Does it Matter? Letöltés: 2020.12.22. Web:

https://www.gettingsmart.com/wpcontent/uploads/2020/04/What-isPlace-Based-Education-and-WhyDoes-it-Matter-4.pdf

Net2: Magyar Közlöny 2020. évi 17. szám. Letöltés: 2020.12.22. Web: https://www.magyarkozlony.hu 